\title{
Sphingomonas aurantiaca sp. nov., Sphingomonas aerolata sp. nov. and Sphingomonas faeni sp. nov., air- and dustborne and Antarctic, orange- pigmented, psychrotolerant bacteria, and emended description of the genus Sphingomonas
}

\section{Correspondence Hans-Jürgen Busse hans-juergen.busse@ vu-wien.ac.at}

\author{
Hans-Jürgen Busse, ${ }^{1,2}$ Ewald B. M. Denner, ${ }^{2}$ Sandra Buczolits, ${ }^{1}$ \\ Mirja Salkinoja-Salonen, ${ }^{3}$ Antonio Bennasar ${ }^{4}$ and Peter Kämpfer ${ }^{5}$ \\ ${ }^{1}$ Institut für Bakteriologie, Mykologie und Hygiene, Veterinärmedizinische Universität, A-1210 \\ Vienna, Austria \\ ${ }^{2}$ Institut für Mikrobiologie und Genetik, Universität Wien, A-1030 Vienna, Austria \\ ${ }^{3}$ Department of Applied Chemistry and Microbiology, POB 56, FIN 00014 University of \\ Helsinki, Finland \\ ${ }^{4}$ Area de Biotecnologia, GridSystems, ParcBIT, Son Espanyol, E-07120 Palma de Mallorca, \\ Spain \\ ${ }^{5}$ Institut für Angewandte Mikrobiologie, Justus-Liebig-Universität Giessen, D-35392 Giessen, \\ Germany
}

\begin{abstract}
Seven psychrotolerant, Gram-negative bacterial strains, five dust- and airborne isolates $\left(\mathrm{MA101} \mathrm{b}^{\top}, \mathrm{MA306a}, \mathrm{MA} 405 / 90, \mathrm{MA}-\mathrm{olki}{ }^{\top}\right.$ and $\mathrm{NW} 12^{\top}$ ) and two from the Antarctic (Ant 20 and M3C203B-B), were subjected to a polyphasic characterization to determine their taxonomic position. High 16S rDNA sequences similarities (99.3-100.0\%) demonstrated that they were closely related to each other. Phylogenetic evaluation of their 16S rDNA sequences revealed that they are members of the genus Sphingomonas sensu stricto, encompassing a separate branch within this genus. They shared $94 \cdot 4-96 \cdot 6 \% 16 \mathrm{~S}$ rDNA sequence similarity with species of this genus. All Sphingomonas-specific signature nucleotides were also detected. The presence of the major ubiquinone Q-10, sym-homospermidine as the predominant polyamine,

Sphingomonadaceae-specific sphingoglycolipid in the polar lipid patterns and a fatty acid profile containing $\mathrm{C}_{14: 0} 2-\mathrm{OH}$ and lacking $3-\mathrm{OH}$ fatty acids were in agreement with identification of these strains as members of the genus Sphingomonas sensu stricto. Results from DNA-DNA hybridizations and comparison of protein patterns indicated that the seven strains are members of three distinct species. One species is represented by strains MA101 ${ }^{\top}, M A 306 a$ and MA405/90, the second by strains NW12 ${ }^{\top}$, Ant 20 and M3C203B-B and the third by one strain, MA-olki ${ }^{\top}$. Their distinction at the species level was also supported by results of biochemical characterization and partly supported by riboprints and genomic fingerprints. On the basis of these results, three novel species of the genus Sphingomonas are proposed: Sphingomonas aurantiaca sp. nov., consisting of strains MA101b $b^{\top}\left(=\mathrm{DSM} 14748^{\top}=\mathrm{LMG} 21377^{\top}\right)$, MA306a and MA405/90 (=DSM $14749=$ LMG 21378), Sphingomonas faeni sp. nov. MA-olki ${ }^{\top}$ $\left(=\mathrm{DSM} 14747^{\top}=\mathrm{LMG} 21379^{\top}\right.$ ) and Sphingomonas aerolata sp. nov., represented by strains NW12 ${ }^{\top}$ (=DSM $14746^{\top}=$ LMG $\left.21376^{\top}\right)$, Ant 20 (=ICMP 13599) and M3C203B-B (=SMCC M3C203B-B).
\end{abstract} faeni MA-olki ${ }^{\top}$ and Sphingomonas aerolata NW12 ${ }^{\top}$ are respectively AJ429236-AJ429240.

Riboprints of the novel isolates and the results of TLC analysis of the polar lipids of a representative strain are available as supplementary material in IJSEM Online. 
Airborne bacteria are of special interest because they have to survive in an unfavourable environment. They are able to withstand increased radiation and desiccation compared with the majority of bacteria, which do not survive for more than a few seconds when suspended in the air (Stetzenbach, 1992). During studies on dustborne bacteria in Finland (Andersson et al., 1999) and airborne bacteria in England (Brimblecombe et al., 1999), five orangepigmented bacterial strains were isolated. Preliminary analyses of the 16S rDNA sequences of the five strains revealed their affiliation with the genus Sphingomonas sensu stricto as defined by Takeuchi et al. (2001). The ability to survive when suspended in the air has not been reported for members of the genus Sphingomonas sensu stricto and, what is more, orange pigmentation is not given in the description of the genus Sphingomonas sensu stricto, which encompasses only yellow- or off-white-pigmented species (Takeuchi et al., 2001).

The genus Sphingomonas, originally described by Yabuuchi et al. (1990), has recently been dissected into four genera (Takeuchi et al., 2001). The genus name Sphingomonas was retained for those species that are most closely related to Sphingomonas paucimobilis, the type species of the genus (cluster I according to Takeuchi et al., 2001). Species of Sphingomonas sensu stricto can be distinguished from species of other genera of the family Sphingomonadaceae by the presence of sym-homospermidine as the predominant compound in the polyamine patterns, several signature nucleotides in the $16 \mathrm{~S}$ rDNA sequences and a combination of other phenotypic markers. The presence of sym-homospermidine as a distinguishing character within the family Sphingomonadaceae is not considered in taxonomic considerations by some scientists (Yabuuchi et al., 1990, 2002), although it reflects the separate phylogenetic position of the genus Sphingomonas sensu stricto. Thus, we strongly support the proposal to retain the genus name Sphingomonas only for the members of cluster I, and the nomenclature of Takeuchi et al. (2001) is used in this report.

Here, classification of these five isolates and two Antarctic Sphingomonas strains (Aislabie et al., 2000; Christner et al., 2000) and their description as three novel species of the genus Sphingomonas are reported.

\section{Isolation and cultivation}

Strains MA101b ${ }^{\mathrm{T}}$, MA306a and MA405/90 were isolated in Spring 1990 and strain MA-olki ${ }^{\mathrm{T}}$ was isolated in December 1998 from cow-barn air when bales of hay and straw were broken open (Andersson et al., 1999). Isolation was done on TSA at $16-18^{\circ} \mathrm{C}$. Strain NW12 $2^{\mathrm{T}}$ was isolated on CasMM agar (Altenburger et al., 1996) in December 1996 during a campaign for collection of airborne micro-organisms in the Sainsbury Centre for Visual Arts in Norwich, UK (Brimblecombe et al., 1999) and was subcultivated at room temperature on PYES agar (Buczolits et al., 2002).

\section{5 rDNA sequence analysis}

$16 \mathrm{~S}$ rDNA was amplified and analysed as described previously (Abraham et al., 1999). Sequence comparisons (ungapped) using FASTA3 (Pearson \& Lipman, 1988) revealed: $99 \cdot 7 \%$ similarity between strain $\mathrm{MA}-\mathrm{olki}^{\mathrm{T}}$ and the three strains MA101b ${ }^{\mathrm{T}}$, MA306a and MA405/90; 99.6\% similarity between strain $\mathrm{NW}^{\mathrm{T}}$ and strains $\mathrm{MA} 101 \mathrm{~b}^{\mathrm{T}}$, MA306a and MA405/90; and 99.3\% similarity between strains $\mathrm{NW}^{\mathrm{T}}{ }^{\mathrm{T}}$ and $\mathrm{MA}$-olki ${ }^{\mathrm{T}}$. Highest similarities were found with sequences of established species of the genus Sphingomonas sensu stricto including Sphingomonas aquatilis KCTC $2881^{\mathrm{T}}(96 \cdot 4-96 \cdot 6 \%)$, Sphingomonas mali IFO $15500^{\mathrm{T}}(95 \cdot 7-96 \cdot 1 \%)$, Sphingomonas pruni IFO $15498^{\mathrm{T}}$ (95.6-96.0\%), Sphingomonas asaccharolytica IFO $15499^{\mathrm{T}}(95 \cdot 5-96 \cdot 0 \%)$, Sphingomonas adhaesiva GIFU $11458^{\mathrm{T}}$ $(95 \cdot 4-96 \cdot 0 \%)$ and Sphingomonas echinoides DSM $1805^{\mathrm{T}}$ $(95 \cdot 9-96 \cdot 0 \%)$. These results clearly demonstrate that the five isolates are members of the genus Sphingomonas sensu stricto. Assignment to the genus Sphingomonas sensu stricto was also confirmed by the presence in the sequences of the five isolates of all signature nucleotides that characterize the genus (Takeuchi et al., 2001). However, the 16S rDNA sequences of the five isolates shared highest similarities with sequences of Sphingomonas strain Ant 20, isolated from hydrocarbon-contaminated soils around Scott Base, Antarctica (Aislabie et al., 2000), Sphingomonas strain M3C203B-B, isolated from ice of Taylor Dome, Antarctica (Christner et al., 2000, 2001), and Sphingomonas strain V21 (accession no. AF324199), isolated from Lake Vostok accretion ice, Antarctica (Christner et al., 2001). Both strains Ant 20 and M3C203B-B showed $99 \cdot 9 \%$ sequence similarity to strain $\mathrm{NW} 12^{\mathrm{T}}, 99 \cdot 6 \%$ to strains $\mathrm{MA} 101 \mathrm{~b}^{\mathrm{T}}$, MA306a and MA405/90 and $99 \cdot 3 \%$ to strain MA-olki ${ }^{\mathrm{T}}$. The sequence of strain V21 was $98 \cdot 2 \%$ similar to those of strains MA101b ${ }^{\mathrm{T}}$, MA306a, MA405/90 and MA-olki ${ }^{\mathrm{T}}$ and $97 \cdot 3 \%$ similar to that of strain $\mathrm{NW} 12^{\mathrm{T}}$. Like our air- and dustborne isolates, strain Ant 20 forms orange-pigmented colonies (Aislabie et al., 2000), as does strain M3C203B-B, whereas V21 is yellow-pigmented (unpublished results). Orange pigmentation is rare among members of the family Sphingomonadaceae and this trait, in addition to psychrotolerance and extraordinarily high sequence similarities, indicated a relationship between strains Ant 20, M3C203B-B and $\mathrm{NW}_{12}{ }^{\mathrm{T}}$ at the species level. Thus, strains Ant 20 and M3C203B-B were included in our study. Strain V21 was not included since it is not orange-pigmented and its $16 \mathrm{~S}$ rDNA sequence similarity to the group of orange-pigmented strains was significantly lower than the similarities between strains within this group.

Nucleotide sequences were aligned with reference $16 \mathrm{~S}$ rDNA sequences using evolutionarily conserved primary sequence and secondary structure (Gutell et al., 1985) as references. Evolutionary distances (Jukes \& Cantor, 1969) were calculated from nearly complete sequence-pair dissimilarities using only homologous, unambiguously determined nucleotide positions. Bootstrap analysis and phylogenetic trees were constructed using programs 
implemented in the PHYLIP package (Felsenstein, 1993). Phylogenetic analysis of nearly full-length $16 \mathrm{~S} \mathrm{rDNA}$ sequences of the five isolates confirmed that they are closely related to each other, as already indicated from sequence similarities, and that they are members of the genus Sphingomonas sensu stricto (Takeuchi et al., 2001), forming a distinct phylogenetic lineage (Fig. 1).

\section{Physiological and biochemical characteristics}

The seven isolates, including Ant 20 and M3C203B-B, grew on TSA at temperatures between 4 and $28^{\circ} \mathrm{C}$, but did not grow at $37^{\circ} \mathrm{C}$. Standard bacteriological and biochemical characterization was carried out as described previously (Denner et al., 2001; Kämpfer et al., 1991), except that the tests were incubated at room temperature for 7 days. Additionally, the strains were studied using API 20NE and API ZYM galleries (bioMérieux), according to the instructions of the manufacturer. Biochemical characteristics were studied as described by Kämpfer et al. (1991). For 103 characteristics tested (Table 1), strains MA101b ${ }^{\mathrm{T}}$, MA306a and MA405/90 were homogeneous and differed from each other in not more than five traits. Another homogeneous group was formed by $\mathrm{NW} 12^{\mathrm{T}}$, Ant 20 and M3C203B-B, which again differed from each other in not more than five

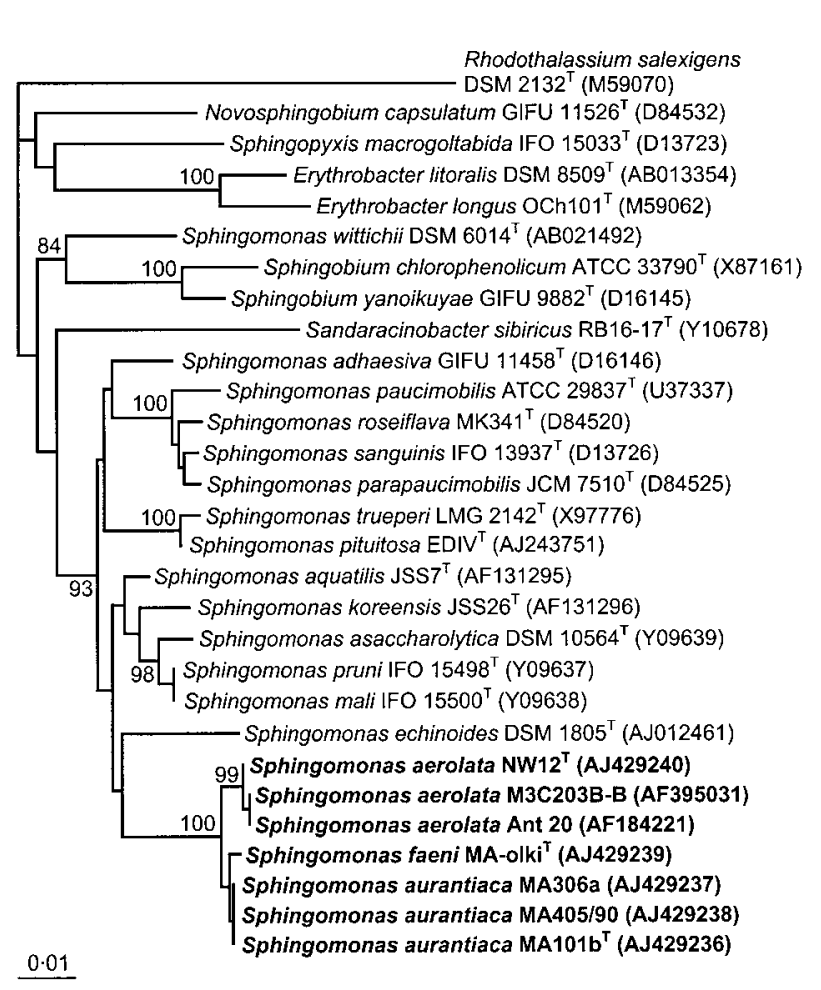

Fig. 1. Estimated $16 \mathrm{~S}$ rDNA phylogenetic relationships among strains MA-olki ${ }^{\top}, \mathrm{NW}_{12}{ }^{\top}, \mathrm{MA} 101 \mathrm{~b}^{\top}, \mathrm{MA} 306 \mathrm{a}$ and MA405/90 and related species of the genus Sphingomonas sensu stricto. Bar, 1 substitution per 100 nucleotide positions. Dataset was resampled 100 times to obtain bootstrap values of confidence. Branching edges for bootstrap values $>70 \%$ are shown. characteristics. These two groups could be distinguished from each other by five traits and from strain $\mathrm{MA}$-olki ${ }^{\mathrm{T}}$ by seven and ten traits, respectively.

\section{Genomic analyses}

Determination of DNA relatedness between the five strains was done as described by Ziemke et al. (1998). The results of DNA-DNA hybridizations (Table 2) demonstrate that strains MA101b ${ }^{\mathrm{T}}$, MA306a and MA405/90 are members of a single species, that strains NW12 ${ }^{\mathrm{T}}$, Ant 20 and M3C203B$\mathrm{B}$ represent another species and that strain MA-olki ${ }^{\mathrm{T}}$ represents a third species. Analysis of genomic DNA using ERIC-PCR (enterobacterial repetitive intergenic consensus PCR) and BOX-PCR (BOX element PCR) (Wieser \& Busse, 2000) revealed unique band patterns (Fig. 2) for strains MA-olki ${ }^{\mathrm{T}}, \mathrm{NW} 12^{\mathrm{T}}$ and MA405/90, whereas genomic fingerprints from strains $\mathrm{MA} 01 \mathrm{~b}^{\mathrm{T}}$ and MA306a were almost indistinguishable. This observation indicates that the latter two strains are clonally related. MA405/90 shared one characteristic band with MA101b ${ }^{\mathrm{T}}$ and MA306a in the ERIC-PCR fingerprint (at approx. $400 \mathrm{bp}$ ) and BOX-PCR fingerprint (at approx. $300 \mathrm{bp}$ ), suggesting moderate relatedness. No significant similarities were observed between the ERIC- and BOX-PCR-generated genomic fingerprints of strains $\mathrm{NW} 12^{\mathrm{T}}$, Ant 20 and M3C203B-B (results not shown). Riboprints were analysed as described previously (Busse et al., 2000). High degrees of similarity were observed between the riboprints of strains MA101b ${ }^{\mathrm{T}}$, MA306a and MA405/90 (>63\%) and strains Ant 20 and M3C203B-B (76\%). No significant similarities $(<54 \%)$ were detected between other riboprints (see Supplementary Fig. A in IJSEM Online). The $\mathrm{G}+\mathrm{C}$ contents of the genomic DNAs were determined from HPLC analyses of nucleosides (Kaneko et al., 1986; Busse et al., 2002). The $\mathrm{G}+\mathrm{C}$ contents of strains MA-olki ${ }^{\mathrm{T}}, \mathrm{NW} 12^{\mathrm{T}}$ and MA101b were respectively $63 \cdot 1,65 \cdot 4$ and $64 \cdot 7 \mathrm{~mol} \%$.

\section{Chemotaxonomic characterization}

Polyamines were analysed as described previously (Busse \& Auling, 1988; Busse et al., 1997). The polyamine patterns of our five isolates and the two Antarctic strains contained predominantly sym-homospermidine. Other polyamines were only detected in trace amounts. This polyamine pattern is a characteristic feature of the genus Sphingomonas sensu stricto as defined previously (Busse et al., 1999; Takeuchi et al., 2001). The quinone systems of the five strains, which were determined by HPLC (Tindall, 1990; Altenburger et al., 1996), consisted predominantly of ubiquinone Q-10 (82-96\%), with small amounts of Q-9 $(3-12 \%)$ and Q-8 (1-6\%). This is in accordance with results for other members of the Sphingomonadaceae (Busse et al., 1999).

Polar lipid profiles were analysed according to the method of Ventosa et al. (1993). For comparability with results from our previous work (Busse et al., 1999), the same designations for unknown lipids that display similar 
Table 1. Biochemical characteristics of orange-pigmented Sphingomonas strains

Taxa: 1, Sphingomonas faeni sp. nov. MA-olki ${ }^{\mathrm{T}}$; 2, Sphingomonas aerolata sp. nov. (3 strains); 3, Sphingomonas aurantiaca sp. nov. (3 strains). +, Positive; $(+)$, weakly positive; -, negative; v, variable. All strains were oxidase- and catalase-positive and assimilated $N$-acetyl-D-glucosamine, L-arabinose, p-arbutin, D-cellobiose, D-fructose, D-galactose, gluconate, D-glucose, D-mannose, D-maltose, sucrose, salicin, D-trehalose, D-xylose, maltitol, fumarate, DL-3-hyroxybutyrate, suberate and L-alanine. All strains assimilated acetate, adipate and oxoglutarate, although weakly positive results were observed for strains Ant 20 and M3C203B-B. All strains hydrolysed aesculin, $p$-nitrophenyl (pNP) $\beta$-D-glucopyranoside, 2-deoxythymidine-5'-pNP phosphate, L-alanine $p$-nitroanilide (pNA) and L-glutamate- $\gamma$-3-carboxy pNA. In API ZYM test, all strains were positive for alkaline phosphatase, esterase (C4), esterase (C8), leucine arylamidase, acidic phosphatase and $\beta$-glucosidase and negative for trypsin, $\alpha$-chymotrypsin, $\alpha$-galactosidase, $\beta$-glucuronidase, $N$-acetyl- $\beta$-glucosaminidase, $\alpha$-mannosidase and $\alpha$-fucosidase. All strains were negative in the $\mathrm{O} / \mathrm{F}$ and Simmons' citrate tests, did not reduce nitrate and did not produce indole or $\mathrm{H}_{2} \mathrm{~S}$. None of the seven strains assimilated D-ribose, adonitol, D-mannitol, D-sorbitol, putrescine, cis-aconitate, 4-aminobutyrate, itaconate, mesaconate, $\beta$-alanine, L-histidine, L-serine, L-ornithine, L-phenylalanine, L-tryptophan, 3-hydroxybenzoate or phenylacetate or hydrolysed starch, casein, gelatin, $\mathrm{pNP} \beta$-D-galactopyranoside, pNP phenylphosphonate or pNP phosphorylcholine.

\begin{tabular}{|c|c|c|c|}
\hline Character & 1 & 2 & 3 \\
\hline \multicolumn{4}{|l|}{ Assimilation of: } \\
\hline L-Rhamnose, DL-lactate, L-aspartate & + & - & - \\
\hline$\alpha$-D-Melibiose, citrate & + & $\mathrm{V}^{a_{\star}}$ & + \\
\hline i-Inositol & - & - & $\mathrm{v}^{e}$ \\
\hline Propionate & + & - & $\mathrm{V}^{f}$ \\
\hline trans-Aconitate & - & - & $\mathrm{V}^{f}$ \\
\hline Azelate, L-leucine & + & - & + \\
\hline Glutarate, pyruvate & + & $\mathrm{v}^{b}$ & + \\
\hline L-Malate & - & $\mathrm{V}^{c}$ & + \\
\hline L-Proline & - & - & + \\
\hline 4-Hydroxybenzoate & - & - & $\mathrm{V}^{g}$ \\
\hline \multicolumn{4}{|l|}{ Hydrolysis of: } \\
\hline pNP $\alpha$-D-glucopyranoside & - & + & $\mathrm{v}^{h}$ \\
\hline bis-pNP phosphate & - & + & + \\
\hline L-Proline pNA & + & - & $\mathrm{V}^{f}$ \\
\hline pNP $\beta$-D-glucuronide & - & + & - \\
\hline DNA & $(+)$ & $(+)$ & $\mathrm{v}^{j}$ \\
\hline \multicolumn{4}{|l|}{ Enzymic activities (API ZYM): } \\
\hline Valine arylamidase & + & + & - \\
\hline$\alpha$-Glucosidase & $(+)$ & + & $\mathrm{V}^{g}$ \\
\hline$\beta$-Galactosidase & $(+)$ & + & $(+)$ \\
\hline Naphthol-AS-BI-phosphohydrolase & $(+)$ & $+{ }^{d}$ & $(+)$ \\
\hline Lipase $(\mathrm{C} 14)$ & - & - & $\mathrm{V}^{k}$ \\
\hline Cystine arylamidase & + & $\mathrm{v}^{a}$ & $\mathrm{~V}^{g}$ \\
\hline
\end{tabular}

${ }^{\star}$ Strain-dependent results are indicated by: $a$, only $\mathrm{NW} 12^{\mathrm{T}}$ positive; $b$, Ant 20 and $\mathrm{M} 3 \mathrm{C} 203 \mathrm{~B}-\mathrm{B}$ weakly positive and NW12 $2^{\mathrm{T}}$ negative; $c$, NW12 ${ }^{\mathrm{T}}$ positive, M3C203B-B weakly positive and Ant 20 negative; $d$, Ant 20 and M3C203B-B weakly positive; $e$, only MA405/90 positive; $f$, only MA405/90 negative; $g$, only MA101b ${ }^{\mathrm{T}}$ negative; $h$, only MA306a negative; $j$, MA306a weakly positive and MA101b ${ }^{\mathrm{T}}$ negative; $k$, only MA101b positive.

chromatographic and staining behaviour are used here. The

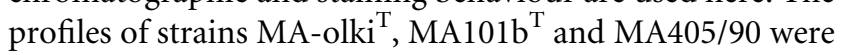
almost identical. They were characterized by the presence of phosphatidyl ethanolamine, phosphatidyl glycerol, phosphatidyl choline, diphosphatidyl glycerol and sphingoglycolipid as the predominant lipids, moderate amounts of phosphatidyl dimethylethanolamine and two unidentified phospholipids (PL3, PL6) and traces of phosphatidyl monomethylethanolamine. Additionally, $\mathrm{MA}-\mathrm{olki}^{\mathrm{T}}$ contained minor amounts of an unidentified aminophospholipid (APL1). NW12 ${ }^{\mathrm{T}}$ could be distinguished from the strains mentioned above by the presence of an unidentified 
Table 2. DNA-DNA relatedness between orange-pigmented Sphingomonas strains

\begin{tabular}{|c|c|c|c|c|}
\hline \multirow[t]{2}{*}{ Source of unlabelled DNA } & \multicolumn{4}{|c|}{ Relatedness (\%) with labelled DNA from: } \\
\hline & MA306a & MA-olki ${ }^{\mathrm{T}}$ & MA405/90 & $\mathrm{NW} 12^{\mathrm{T}}$ \\
\hline MA306a & 100 & 60 & 100 & ND \\
\hline MA $101 b^{T}$ & 118 & 52 & 91 & ND \\
\hline MA 405 & 81 & 51 & 100 & ND \\
\hline MA-olki ${ }^{\mathrm{T}}$ & 57 & 100 & 61 & ND \\
\hline $\mathrm{NW} 12^{\mathrm{T}}$ & 48 & 35 & 35 & 100 \\
\hline Ant 20 & ND & ND & ND & $71^{*}$ \\
\hline M3C203B-B & ND & ND & ND & $107 \dagger$ \\
\hline Sphingomonas paucimobilis NCTC $11030^{\mathrm{T}}$ & 29 & 29 & 29 & $\mathrm{ND}$ \\
\hline Pooled SD & $4 \cdot 1$ & $4 \cdot 9$ & $5 \cdot 1$ & \\
\hline
\end{tabular}

${ }^{\star}$ Mean of three measurements (relatedness values of 62,68 and $84 \%$ ).

$\dagger$ Mean of three measurements (relatedness values of 103, 109 and $109 \%$ ).

ND, Not determined.

phospholipid (PL5), an aminophospholipid (APL2) and three glycolipids (GL1, GL4, GL5) (see Supplementary Fig. B in IJSEM Online). The polar lipid profile of strain M3C203B-B was almost identical to that of $\mathrm{NW}_{12}{ }^{\mathrm{T}}$. The polar lipid profile of strain Ant 20 resembled those of NW12 ${ }^{\mathrm{T}}$ and M3C203B-B, but it could be distinguished from these two strains by the presence of small amounts of three unidentified, additional phospholipids and an aminophospholipid. These polar lipid profiles clearly distinguished the strains studied here from members of the Sphingomonadaceae (Busse et al., 1999), including Blastomonas natatoria DSM $3183^{\mathrm{T}}$, a strain that turns from yellow to orange as cultures age.

During analysis of polar lipids, it was revealed that the

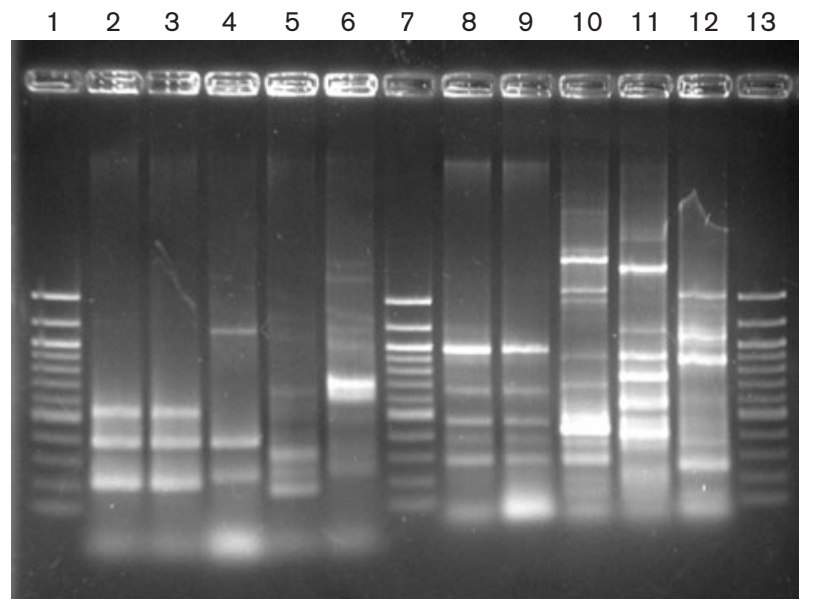

Fig. 2. Genomic fingerprints of the five orange-pigmented isolates generated by ERIC-PCR (lanes 2-6) and BOX-PCR (8-12). Lanes: 1,7 and $13,100 \mathrm{bp}$ ladder; 2 and 8 , MA101 $\mathrm{b}^{\top} ; 3$ and 9, MA306a; 4 and 10, MA405/90; 5 and 11, MA-olki ${ }^{\top} ; 6$ and $12, \mathrm{NW}_{12}{ }^{\mathrm{T}}$. orange pigmentation of the isolates resulted from the presence of different orange compounds. Analysis of acetoneextracted pigments (Denner et al., 2001) of the seven strains displayed spectra that were indicative only for yellow pigments. The spectra obtained were similar, but not identical, to those reported for other sphingomonads, including strains of Sphingomonas paucimobilis, Sphingomonas trueperi (Jenkins et al., 1979), Sphingomonas pituitosa DSM $13101^{\mathrm{T}}$ (Denner et al., 2001), Novosphingobium capsulatum LMG $2830^{\mathrm{T}}$ (Bally et al., 1990), Sphingomonas xenophaga DSM $6383^{\mathrm{T}}$ (Stolz et al., 2000), which can be considered to be a member of the genus Sphingobium (Takeuchi et al., 2001), and Erythrobacter citreus DSM $14432^{\mathrm{T}}$ (Denner et al., 2002). The spectral characteristics of the extracted pigments of the strains were as follows: $\mathrm{MA101b}^{\mathrm{T}}$, MA306a, Ant 20 and M3C203B-B, $\lambda_{\max }$ at 458 and $478 \mathrm{~nm} ; \mathrm{MA} 405 / 90, \lambda_{\max }$ at 457 and $478 \mathrm{~nm} ; \mathrm{MA}$-olki ${ }^{\mathrm{T}}$, $\lambda_{\max }$ at 458 and $474 \mathrm{~nm}$; and $\mathrm{NW} 12^{\mathrm{T}}, \lambda_{\max }$ at 458 and 476-477 nm. Several spectra showed slight inflexions at approximately $425 \mathrm{~nm}$.

Fatty acids were analysed from biomass that was grown for $72 \mathrm{~h}$ on TSA at $28^{\circ} \mathrm{C}$ as described by Kämpfer et al. (1997). The seven strains displayed almost identical fatty acid profiles, including the presence of $\mathrm{C}_{14: 0} 2$-OH and the absence of any 3-OH fatty acids (Table 3 ). These profiles are in excellent agreement with those of representatives of the genus (Kämpfer et al., 1997; Busse et al., 1999; Denner et al., 2001) and their assignment to the genus Sphingomonas sensu stricto.

Almost identical protein band patterns obtained after SDSPAGE (Altenburger et al., 1996) indicated that strains MA101b $^{\mathrm{T}}$, MA306a and MA405/90 are strains of a single species, NW12 ${ }^{\mathrm{T}}$, Ant 20 and M3C203B-B are members of another species and MA-olki ${ }^{\mathrm{T}}$ represents a third species (results not shown). These observations are in agreement with results from $16 \mathrm{~S}$ rDNA sequence comparisons, DNADNA hybridizations and polar lipid profiles. 
Table 3. Fatty acid compositions of Sphingomonas faeni, Sphingomonas aerolata and Sphingomonas aurantiaca

Species: 1, Sphingomonas faeni sp. nov. MA-olki ${ }^{\mathrm{T}}$; 2, Sphingomonas aerolata sp. nov. strains $\mathrm{NW} 12^{\mathrm{T}}$, Ant 20 and M3C203B-B; 3, Sphingomonas aurantiaca sp. nov. strains MA101b ${ }^{\mathrm{T}}$, MA306a and MA405/90. Values are percentages of total fatty acids. The position of the double bond can be located by counting from the methyl $(\omega)$ end of the carbon chain. Summed features represent groups of two or three fatty acids that could not be separated by GLC with the MIDI system. Summed feature 4 contains one or more of $\mathrm{C}_{16: 1} \omega 7 c$ and/or $\mathrm{C}_{15: 0}$ iso 2-OH. Summed feature 7 contains one or more of $\mathrm{C}_{18: 1} \omega 7 c, \mathrm{C}_{18: 1} \omega 9 t$ and/or $\mathrm{C}_{18: 1} \omega 12 t$ (cis and trans isomers are indicated by the suffixes $c$ and $t$, respectively).

\begin{tabular}{|lccc|}
\hline Fatty acid & $\mathbf{1}$ & $\mathbf{2}$ & $\mathbf{3}$ \\
\hline $\mathrm{C}_{14: 0}$ & $2 \cdot 0$ & $1 \cdot 6-1 \cdot 9$ & $2 \cdot 1-3 \cdot 0$ \\
$\mathrm{C}_{12: 0} 2-\mathrm{OH}$ & $0 \cdot 6$ & $0 \cdot 3-0 \cdot 6$ & $0 \cdot 4$ \\
$\mathrm{C}_{14: 0} 2-\mathrm{OH}$ & $9 \cdot 7$ & $8 \cdot 7-14 \cdot 1$ & $10 \cdot 0-10 \cdot 6$ \\
$\mathrm{C}_{15: 0}$ & & $0 \cdot 0-0 \cdot 5$ & $0 \cdot 0-0 \cdot 8$ \\
Summed feature 4 & $29 \cdot 2$ & $24 \cdot 6-26 \cdot 8$ & $25 \cdot 7-28 \cdot 0$ \\
$\mathrm{C}_{16: 1} \omega 5 c$ & $1 \cdot 6$ & $1 \cdot 2-2 \cdot 0$ & $1 \cdot 6-1 \cdot 8$ \\
$\mathrm{C}_{16: 0}$ & $11 \cdot 2$ & $12 \cdot 0-15 \cdot 8$ & $12 \cdot 2-15 \cdot 6$ \\
$\mathrm{C}_{17: 0}$ cyclo & & $0 \cdot 0-0 \cdot 4$ & \\
$\mathrm{C}_{17: 1} \omega 6 c$ & $2 \cdot 6$ & $0 \cdot 0-1 \cdot 7$ & $0 \cdot 8-3 \cdot 0$ \\
$\mathrm{C}_{17: 1} \omega 8 c$ & & & $0 \cdot 0-0 \cdot 4$ \\
$\mathrm{C}_{16: 1} 2-\mathrm{OH}$ & & $0 \cdot 0-0 \cdot 5$ & \\
$\mathrm{C}_{17: 0}$ & & & $0 \cdot 0-0 \cdot 2$ \\
Summed feature $7_{\mathrm{C}_{18: 1} \omega 5 c}$ & $41 \cdot 4$ & $38 \cdot 5-46 \cdot 0$ & $40 \cdot 0-40 \cdot 5$ \\
$\mathrm{C}_{18: 0}$ & $1 \cdot 0$ & $0 \cdot 6-0 \cdot 8$ & $0 \cdot 6-1 \cdot 0$ \\
$\mathrm{C}_{19: 0}$ cyclo $\omega 8 c$ & & & $0 \cdot 0-0 \cdot 3$ \\
$11-$ methyl $\mathrm{C}_{18: 1} \omega 7 c$ & & & $0 \cdot 4-0 \cdot 7$ \\
& & & $0 \cdot 0-3 \cdot 5$ \\
\hline
\end{tabular}

\section{Taxonomic considerations}

Polyphasic classification of the dustborne strains MA101b ${ }^{\mathrm{T}}$, MA306a, MA405/90 and MA-olki ${ }^{\mathrm{T}}$, the airborne strain NW12 ${ }^{\mathrm{T}}$ and the two Antarctic strains Ant 20 and M3C203B$\mathrm{B}$ demonstrated that they are closely related to each other and members of the genus Sphingomonas sensu stricto (Takeuchi et al., 2001). Results from $16 \mathrm{~S}$ rDNA analyses, DNA-DNA hybridizations, riboprint analyses, ERIC- and BOX-PCR, polar lipid profiles and protein patterns separated strains MA101b ${ }^{\mathrm{T}}$, MA306a and MA405/90 from the other four strains. 16S rDNA analyses, DNA similarities and protein patterns suggest that strains NW12 ${ }^{\mathrm{T}}, \mathrm{M} 3 \mathrm{C} 203 \mathrm{~B}-\mathrm{B}$ and Ant 20 form a second group that is heterogeneous in terms of genomic fingerprints and partly heterogeneous in polar lipid profiles and riboprint patterns. Strain MAolki $^{\mathrm{T}}$ can be distinguished from the other strains by its $16 \mathrm{~S}$ rDNA sequence, DNA similarity data, genomic fingerprints, riboprint patterns, protein patterns and polar lipid profiles. Biochemical traits support the distinction of the seven strains into three groups. Based on these results, it is concluded that our five isolates and the two Antarctic strains represent three novel species of the genus Sphingomonas sensu stricto. Therefore, the names Sphingomonas aerolata sp. nov. (for strains $\mathrm{NW}_{12}^{\mathrm{T}}$, Ant 20 and M3C203B-B), Sphingomonas faeni sp. nov. (for strain MA-olki ${ }^{\mathrm{T}}$ ) and Sphingomonas aurantiaca sp. nov. (for strains $\mathrm{MA}^{\mathrm{T}} 101 \mathrm{~b}^{\mathrm{T}}$, MA306a and MA405/90) are proposed.

The affiliation of these species, which differ from the genus description in their pigmentation and cell sizes, to the genus Sphingomonas sensu stricto (Takeuchi et al., 2001), as well as the lack of information concerning polar lipid compositions within the genus (Busse et al., 1999), suggests that the description of the genus Sphingomonas should be emended.

\section{Emended description of the genus Sphingomonas Yabuuchi et al. 1990 emend. Takeuchi et al. 2001}

Cells are $0 \cdot 3-0.8 \times 1 \cdot 0-2 \cdot 7 \mu \mathrm{m}$. Colonies are off-white-, yellow- or orange-pigmented. The polar lipid profiles contain the following, in addition to sphingoglycolipid: phosphatidyl glycerol as predominant lipid, moderate to large amounts of phosphatidyl ethanolamine, diphosphatidyl glycerol, phosphatidyl dimethylethanolamine and phosphatidyl choline, varying amounts of phosphatidyl monomethylethanolamine and varying numbers of unidentified polar lipids (Busse et al., 1999). Other characteristics of the genus are those given by Takeuchi et al. (2001).

\section{Description of Sphingomonas aerolata sp. nov.}

Sphingomonas aerolata (ae.ro.la'ta. Gr. fem. n. aer air; L. part. adj. lata carried; N.L. part. adj. aerolata airborne).

Cells are small rods, $0 \cdot 6-0 \cdot 8 \times 1 \cdot 5-2 \cdot 6 \mu \mathrm{m}$. Growth is observed on Czapek-Dox, R2A, CasMM, PYES and TSA, but not on MacConkey agar. Cells occur singly or sometimes in short chains. Cells grow at $4-28^{\circ} \mathrm{C}$, but not at $37^{\circ} \mathrm{C}$. Gram-negative as determined by Gram staining, $\mathrm{KOH}$ and aminopeptidase tests. Motile. Endospores not observed. Colonies are circular, slightly convex, opaque and orangepigmented. Aerobic. Catalase- and oxidase-positive. Nitrate is not reduced. Strain Ant 20 mineralizes phenanthrene and 1-methyl naphthalene (Aislabie et al., 2000). Other physiological and biochemical traits are shown in Table 1. Polar lipid profile consists of phosphatidyl ethanolamine, phosphatidyl glycerol, phosphatidyl choline, diphosphatidyl glycerol, sphingoglycolipid and unknown glycolipid 1 as the predominant lipids, moderate amounts of phosphatidyl dimethylethanolamine, three unidentified phospholipids and two glycolipids and traces of phosphatidyl monomethylethanolamine and an unidentified aminophospholipid. Three unidentified phospholipids and an aminophospholipid may also be present. Predominant compounds in the fatty acid profile are summed feature 7 $\left(\mathrm{C}_{18: 1} \omega 7 c, \mathrm{C}_{18: 1} \omega 9 t\right.$ and/or $\left.\mathrm{C}_{18: 1} \omega 12 t\right)$, summed feature 4 $\left(\mathrm{C}_{16: 1} \omega 7 c\right.$ and/or $\mathrm{C}_{15: 0}$ iso 2-OH), $\mathrm{C}_{16: 0}$ and $\mathrm{C}_{14: 0} 2-\mathrm{OH}$. Major quinone is ubiquinone Q-10. Predominant polyamine is sym-homospermidine. Acetone-soluble pigment is 
characterized by $\lambda_{\max }$ at 458 and $476-478 \mathrm{~nm}$. The $\mathrm{G}+\mathrm{C}$ content of genomic DNA of the type strain is $65 \cdot 4 \mathrm{~mol} \%$.

The type strain, $\mathrm{NW}_{12}{ }^{\mathrm{T}}\left(=\mathrm{DSM} 14746^{\mathrm{T}}=\mathrm{LMG} 21376^{\mathrm{T}}\right)$, was isolated from air in the Sainsbury Centre for Visual Arts, Norwich, UK. Strain Ant 20 (= NCMP 13599) was isolated from hydrocarbon-contaminated soils around Scott Base, Antarctica (Aislabie et al., 2000), and strain M3C203B-B ( = SMCC M3C203B-B) was isolated from 4200-year-old ice of Taylor Dome, Antarctica (Christner et al., 2000, 2001).

\section{Description of Sphingomonas faeni sp. nov.}

Sphingomonas faeni (fae'ni. L. gen. n. faeni of hay).

Cells are small rods, $0 \cdot 6-0 \cdot 8 \times 2 \cdot 0-2 \cdot 6 \mu \mathrm{m}$. Growth is observed on Czapek-Dox, R2A, CasMM, PYES and TSA, but not on MacConkey agar. Cells occur singly or sometimes in short chains. Cells grow on TSA at $4-28^{\circ} \mathrm{C}$, but not at $37^{\circ} \mathrm{C}$. Gram-negative as determined by Gram staining, $\mathrm{KOH}$ and aminopeptidase tests. Motile. Endospores not observed. Colonies are circular, slightly convex, opaque and orange-pigmented. Aerobic. Catalase- and oxidasepositive. Nitrate is not reduced. Other physiological and biochemical traits are shown in Table 1. Polar lipid profile consists of phosphatidyl ethanolamine, phosphatidyl glycerol, phosphatidyl choline, diphosphatidyl glycerol and sphingoglycolipid as the predominant lipids, moderate amounts of phosphatidyl dimethylethanolamine and two unidentified phospholipids and traces of phosphatidyl monomethylethanolamine and an unidentified aminophospholipid. Predominant compounds in the fatty acid profile are summed feature $7\left(\mathrm{C}_{18: 1} \omega 7 c, \mathrm{C}_{18: 1} \omega 9 t\right.$ and/or $\left.\mathrm{C}_{18: 1} \omega 12 t\right)$, summed feature $4\left(\mathrm{C}_{16: 1} \omega 7 c\right.$ and/or $\mathrm{C}_{15: 0}$ iso 2-OH), $\mathrm{C}_{16: 0}$ and $\mathrm{C}_{14: 0}$ 2-OH. Major quinone is ubiquinone Q-10. Predominant polyamine is sym-homospermidine. Acetone-soluble pigment is characterized by $\lambda_{\max }$ at $457-458$ and $478 \mathrm{~nm}$. The $\mathrm{G}+\mathrm{C}$ content of genomic DNA of the type strain is $63 \cdot 1 \mathrm{~mol} \%$.

The type strain, MA-olki ${ }^{\mathrm{T}}\left(=\mathrm{DSM} 14747^{\mathrm{T}}=\mathrm{LMG} 21379^{\mathrm{T}}\right)$, was isolated from whirled-up dust in a cow barn, Finland.

\section{Description of Sphingomonas aurantiaca sp. nov.}

Sphingomonas aurantiaca (au.ran.ti.a'ca. M.L. fem. adj. aurantiaca orange-coloured).

Cells are small rods, $0 \cdot 6-0 \cdot 8 \times 1 \cdot 0-2 \cdot 7 \mu \mathrm{m}$. Growth is observed on Czapek-Dox, R2A, CasMM, PYES and TSA, but not on MacConkey agar. Cells occur singly or sometimes in short chains. Cells grow on TSA at $4-28^{\circ} \mathrm{C}$, but not at $37^{\circ} \mathrm{C}$. Gram-negative as determined by Gram staining, $\mathrm{KOH}$ and aminopeptidase tests. Motile. Endospores not observed. Colonies are circular, slightly convex, opaque and orange-pigmented. Aerobic. Catalase- and oxidase-positive. Nitrate is not reduced. Other physiological and biochemical traits are shown in Table 1. Polar lipid profile consists of phosphatidyl ethanolamine, phosphatidyl glycerol, phosphatidyl choline, diphosphatidyl glycerol and sphingoglycolipid as the predominant lipids, moderate amounts of phosphatidyl dimethylethanolamine and two unidentified phospholipids and traces of phosphatidyl monomethylethanolamine. Predominant compounds in the fatty acid profile are summed feature $7\left(\mathrm{C}_{18: 1} \omega 7 c, \mathrm{C}_{18: 1} \omega 9 t\right.$ and/or $\left.\mathrm{C}_{18: 1} \omega 12 t\right)$, summed feature $4\left(\mathrm{C}_{16: 1} \omega 7 \mathrm{c}\right.$ and/or $\mathrm{C}_{15: 0}$ iso 2-OH), $\mathrm{C}_{16: 0}$ and $\mathrm{C}_{14: 0}$ 2-OH. Major quinone is ubiquinone Q-10. Predominant polyamine is sym-homospermidine. Acetone-soluble pigment is characterized by $\lambda_{\max }$ at 458 and $476-477 \mathrm{~nm}$. The $\mathrm{G}+\mathrm{C}$ content of genomic DNA of the type strain is $64 \cdot 7 \mathrm{~mol} \%$.

The type strain, MA101b ${ }^{\mathrm{T}}\left(=\mathrm{DSM} 14748^{\mathrm{T}}=\mathrm{LMG} 21377^{\mathrm{T}}\right)$, and strains MA405/90 (=DSM 14749=LMG 21378) and MA306a were isolated from whirled-up dust in a cow barn, Finland.

\section{Acknowledgements}

Parts of this work were supported by Project AER from the European Commission in the R\&D Programme Environment and Climate, contract no. ENV4-CT95-088. A. B. acknowledges the support of grants BIO91-0659 and MAR91-0341 from the Comision Interministerial de Ciencia y Tecnología (CICYT). We are grateful to Jackie Aislabie and Brent Christner for providing strains Ant 20 and M3C203B-B and to Douwe Hoornstra for riboprint analyses of strains Ant 20 and M3C203B-B.

\section{References}

Abraham, W. R., Strömpl, C. Meyer, H. \& 8 other authors (1999). Phylogeny and polyphasic taxonomy of Caulobacter species. Proposal of Maricaulis gen. nov. with Maricaulis maris (Poindexter) comb. nov. as the type species, and emended description of the genera Brevundimonas and Caulobacter. Int J Syst Bacteriol 49, 1053-1073.

Aislabie, J., Foght, J. \& Saul, D. (2000). Aromatic hydrocarbondegrading bacteria from oil near Scott Base, Antarctica. Polar Biol 23, $183-188$.

Altenburger, P., Kämpfer, P., Makristathis, A., Lubitz, W. \& Busse, H.-J. (1996). Classification of bacteria isolated from a medieval wall painting. J Biotechnol 47, 39-52.

Andersson, M. A., Weiss, N., Rainey, F. A. \& Salkinoja-Salonen, M. S. (1999). Dust-borne bacteria in animal sheds, schools and children's day care centers. J Appl Microbiol 86, 622-634.

Bally, R., Givaudan, A., Bernillon, J., Heulin, T., Balandreau, J. \& Bardin, R. (1990). Numerical taxonomic study of three $\mathrm{N}_{2}$-fixing yellow-pigmented bacteria related to Pseudomonas paucimobilis. Can J Microbiol 36, 850-855.

Brimblecombe, P., Blades, N. Camuffo, D. \& 8 other authors (1999). The indoor environment of a modern museum building, the Sainsbury Centre for Visual Arts, Norwich, UK. Indoor Air 9, 146-164.

Buczolits, S., Denner, E. B. M., Vybiral, D., Wieser, M., Kämpfer, P. \& Busse, H.-J. (2002). Classification of three airborne bacteria and proposal of Hymenobacter aerophilus sp. nov. Int J Syst Evol Microbiol 52, 445-456.

Busse, J. \& Auling, G. (1988). Polyamine patterns as a chemotaxonomic marker within the Proteobacteria. Syst Appl Microbiol 11, 1-8. 
Busse, H.-J., Bunka, S., Hensel, A. \& Lubitz, W. (1997). Discrimination of members of the family Pasteurellaceae based on polyamine patterns. Int J Syst Bacteriol 47, 698-708.

Busse, H.-J., Kämpfer, P. \& Denner, E. B. M. (1999). Chemotaxonomic characterisation of Sphingomonas. J Ind Microbiol Biotechnol 23, 242-251.

Busse, H.-J., Kainz, A., Tsitko, I. V. \& Salkinoja-Salonen, M. (2000). Riboprints as a tool for rapid preliminary identification of sphingomonads. Syst Appl Microbiol 23, 115-123.

Busse, H.-J., Kämpfer, P. Moore, E. R. B. \& 7 other authors (2002). Thermomonas haemolytica gen. nov., sp. nov., a $\gamma$-proteobacterium from kaolin slurry. Int J Syst Evol Microbiol 52, 473-483.

Christner, B. C., Mosley-Thompson, E., Thompson, L. G., Zagorodnov, V., Sandman, K. \& Reeve. J. N. (2000). Recovery and identification of viable bacteria immured in glacial ice. Icarus 144, 479-485.

Christner, B. C., Mosley-Thompson, E., Thompson, L. G. \& Reeve, J. N. (2001). Isolation of bacteria and $16 \mathrm{~S}$ rDNAs from Lake Vostok accretion ice. Environ Microbiol 3, 570-577.

Denner, E. B. M., Paukner, S., Kämpfer, P., Moore, E. R. B., Abraham, W.-R., Busse, H.-J., Wanner, G. \& Lubitz, W. (2001). Sphingomonas pituitosa sp. nov., an exopolysaccharide-producing bacterium that secretes an unusual type of sphingan. Int J Syst Evol Microbiol 51, 827-841.

Denner, E. B. M., Vybiral, D., Kobližek, M., Kämpfer, P., Busse, H.-J. \& Velimirov, B. (2002). Erythrobacter citreus sp. nov., a yellowpigmented bacterium that lacks bacteriochlorophyll $a$, isolated from the western Mediterranean Sea. Int J Syst Evol Microbiol 52, 1655-1661.

Felsenstein, J. (1993). PHYLIP (phylogenetic inference package), version 3.5c. Department of Genetics, University of Washington, Seattle, WA, USA.

Gutell, R. R., Weiser, B., Woese, C. R. \& Noller, H. F. (1985). Comparative anatomy of 16-S-like ribosomal RNA. Prog Nucleic Acids Res Mol Biol 32, 155-216.

Jenkins, C. L., Andrewes, A. G., McQuade, T. J. \& Starr, M. P. (1979). The pigment of Pseudomonas paucimobilis is a carotenoid (nostoxanthin) rather than a brominated aryl-polyene (xanthomonadin). Curr Microbiol 3, 1-4.

Jukes, T. H. \& Cantor, C. R. (1969). Evolution of protein molecules. In Mammalian Protein Metabolism, vol. 3, pp. 21-132. Edited by H. N. Munro. New York: Academic Press.

Kämpfer, P., Steiof, M. \& Dott, W. (1991). Microbiological characterization of a fuel-oil contaminated site including numerical identification of heterotrophic water and soil bacteria. Microb Ecol 21, 227-251.
Kämpfer, P., Denner, E. B. M., Meyer, S., Moore, E. R. B. \& Busse, H.-J. (1997). Classification of 'Pseudomonas azotocolligans' Anderson 1955, 132, in the genus Sphingomonas as Sphingomonas trueperi sp. nov. Int J Syst Bacteriol 47, 577-583.

Kaneko, T., Katoh, K., Fujimoto, M., Kumagi, M., Tamaoka, J. \& Katayama-Fujimura, Y. (1986). Determination of the nucleotide composition of a deoxyribonucleic acid by high-performance liquid chromatography of its enzymatic hydrolysates: a review. J Microbiol Methods 4, 229-240.

Pearson, W. R. \& Lipman, D. J. (1988). Improved tools for biological sequence comparison. Proc Natl Acad Sci U S A 85, 2444-2448.

Stetzenbach, L. D. (1992). Airborne microorganisms. In Encyclopedia of Microbiology, vol. 1, pp. 53-65. Edited by J. Lederberg. San Diego: Academic Press.

Stolz, A., Schmidt-Maag, C., Denner, E. B. M., Busse, H.-J., Egli, T. \& Kämpfer, P. (2000). Description of Sphingomonas xenophaga sp. nov. for strain $\mathrm{BN6}^{\mathrm{T}}$ and $\mathrm{N}, \mathrm{N}$, which degrade xenobiotic aromatic compounds. Int J Syst Evol Microbiol 50, 35-41.

Takeuchi, M., Hamana, K. \& Hiraishi, A. (2001). Proposal of the genus Sphingomonas sensu stricto and three new genera, Sphingobium, Novosphingobium and Sphingopyxis, on the basis of phylogenetic and chemotaxonomic analyses. Int $J$ Syst Evol Microbiol 51, 1405-1417.

Tindall, B. J. (1990). Lipid composition of Halobacterium lacusprofundi. FEMS Microbiol Lett 66, 199-202.

Ventosa, A., Marquez, M. C., Kocur, M. \& Tindall, B. J. (1993). Comparative study of 'Micrococcus sp.' strains CCM 168 and CCM 1405 and members of the genus Salinicoccus. Int J Syst Bacteriol 43, 245-248.

Wieser, M. \& Busse, H.-J. (2000). Rapid identification of Staphylococcus epidermidis. Int J Syst Evol Microbiol 50, 1087-1093.

Yabuuchi, E., Yano, I., Oyaizu, H., Hashimoto, Y., Ezaki, T. \& Yamamoto, H. (1990). Proposals of Sphingomonas paucimobilis gen. nov. and comb. nov., Sphingomonas parapaucimobilis sp. nov., Sphingomonas yanoikuyae sp. nov., Sphingomonas adhaesiva sp. nov., Sphingomonas capsulata comb. nov., and two genospecies of the genus Sphingomonas. Microbiol Immunol 34, 99-119.

Yabuuchi, E., Kosako, Y., Fujiwara, N., Naka, T., Matsunaga, I., Ogura, H. \& Kobayashi, K. (2002). Emendation of the genus Sphingomonas Yabuuchi et al. 1990 and junior objective synonymy of the species of three genera, Sphingobium, Novosphingobium and Sphingopyxis, in conjunction with Blastomonas ursincola. Int J Syst Evol Microbiol 52, 1485-1496.

Ziemke, F., Höfle, M. G., Lalucat, J. \& Roselló-Mora, R. (1998). Reclassification of Shewanella putrefaciens Owen's genomic group II as Shewanella baltica sp. nov. Int J Syst Bacteriol 48, 179-186. 